Беляев Дмитрий Анатольевич

кандидат философских наук,

доцент кафедры философии, социологии и теологии

Института истории, права и общественных наук

Липецкого государственного педагогического

университета имени П.П. Семенова-Тян-Шанского

\section{Каткова Ульяна Сергеевна}

студентка Института филологии

Липецкого государственного педагогического

университета имени П.П. Семенова-Тян-Шанского

\section{НАРОДНО-МОНАРХИЧЕСКАЯ ИМПЛЕМЕНТАЦИЯ ПУБЛИЧНОГО ИНТЕРЕСА В ПОЛИТИКО-ПРАВОВОЙ КОНЦЕПЦИИ И.Л. СОЛОНЕВИЧА}

\section{Аннотация:}

В статье рассмотрено содержательное определение кониепта «публичный интерес» в творчестве И.Л. Солоневича в широком политико-правовом контексте. Отдельно обозначены государственноправовые, историко-культурные основания и национальные характеристики публичного интереса. Проанализирована категория «народной монархии» как политико-правовой феномен, наиболее адекватно отражающий публичный интерес Российского государства. Русский мыслитель указывал на необходимость на первый взгляд парадоксального сочетания самодержавия, самоуправления и бессословности, выступающих «скрепами» отечественной государственности. Выявлены славянофильские основания в учении И.Л. Солоневича, его опора на культурно-историческую исключительность генеалогии и генезиса русской государственности. Исследована критическая аргументация И.Л. Солоневича относительно республиканской формы правления. В заключение сделан вывод - самобытности, национальной укорененности теоретической имплементации И.Л. Солоневичем российского публичного интереса через концепцию «народной монархии».

Ключевые слова:

Солоневич, публичный интерес, «народная монархия», самодержавие, "соборная монархия», консерватизм.
Belyaev Dmitriy Anatolyevich

PhD, Assistant Professor Philosophy, Sociology and Theology Department, Institute of History, Law and Social Sciences Lipetsk State Pedagogical University

\section{Katkova Ulyana Sergeevna}

Student, Institute of Philology, Lipetsk State Pedagogical University

\section{THE NATIONAL AND MONARCHICAL IMPLEMENTATION OF PUBLIC INTEREST IN THE POLITICAL AND LEGAL CONCEPT OF I.L. SOLONEVICH}

Summary:

The article determines the concept of "public interest" in the works of I.L. Solonevich in a broad political and legal context. The authors make particular reference to the state, legal, historical and cultural grounds and the national characteristics of public interest. The "national monarchy" is analyzed as a political and legal phenomenon that reflects the public interest of the Russian state in an appropriate manner. At first, the Russian thinker points to the necessity of a paradoxical combination of autocracy, self-government and absence of stratification acting as the "bracers" of Russian statehood. It is further revealed the Slavophilic grounds in the theory of I.L. Solonevich, its reliance on the cultural and historical exclusiveness of genealogy and the genesis of Russian statehood. Moreover, the article investigates the critical reasoning for the republican form of government by the thinker. Finally, it is concluded about the identity, the national rootedness of the theoretical implementation of the Russian public interest by I.L. Solonevich through the concept of "national monarchy".

Keywords:

Solonevich, public interest, "national monarchy", autocracy, "conciliar monarchy", conservatism.

Вопрос о содержательном раскрытии концепта «публичный интерес» продолжает сохранять актуальность в современном политико-правовом дискурсе. Теоретически публичный интерес обозначает совокупность общегосударственных и/или общественных позитивных потребностей/целей, обладающих легальной юридической закрепленностью или стремящихся к ней. По сути он выступает интегралом общественной потребности, служащей цели обеспечения положительного функционирования и перспективного развития общества как единого социального организма. При этом его определение всегда содержательно наполняется в рамках конкретной государственно-общественной общности, отражая культурно-исторически сложившиеся ценности, потребности и представления о должной, лучшей государственно-правовой и социальной организации. С учетом особой цивилизационной судьбы России думается, что механический перенос на нее представлений о публичном интересе, присущих западноевропейским странам, принципиально ошибочен.

В современном российском научно-правовом и широком общественном дискурсе наблюдается попытка сформулировать определение публичного интереса применительно к России, 
основываясь на ее культурных ценностях, политической, правовой и социальной истории. В связи с этим особый интерес вызывают отечественные мыслители, пытавшиеся содержательно охарактеризовать данное понятие исходя из национальных традиций нашей страны. Здесь с учетом ренессанса консервативной, державно-традиционалистской политической идеологии [1, S. 58-59] новое, актуальное звучание обретает политико-правовая концепция И.Л. Солоневича с ее народно-монархической модальностью определения публичного интереса России.

Итак, в своем ви́дении публичного интереса И.Л. Солоневич доказывал, что сущность государственно-политической потребности России заключается в «народной монархии» как институционально оптимальной и культурно-исторически укорененной фрорме государственно-правового и социального устройства. Выступая с позиций патриархальной теории государства, мыслитель говорил об историческом развитии монархии как формы верховной власти [2, с. 43-47]. По его мнению, монархия родилась органически, даже биологически: из семьи, переросшей в род, рода, переросшего в племя, и т. д. Он сформулировал психологические черты нации-строительницы и инкорпорировал их в собственное понимание публичного интереса Российского государства. «Психология, "дух" народа-строителя, который втягивает в свою орбиту другие нации» [3, с. 332], - вот что является определяющим фрактором любого государственного строительства. Понять русскую государственность, политические идеи - значит понять психологию русского народа.

И.Л. Солоневич, апеллируя к множеству исторических примеров, утверждал, что именно самодержавие как особый вид монархического правления было наиболее адекватно национальному публичному интересу России. Одновременно проблему самодержавия мыслитель считал одним из особо трудных вопросов монархической теории. По мнению Ивана Лукьяновича, абсолютная власть монарха является мифом, поскольку она невозможна практически. Власть монарха выступает исключительно некой равнодействующей всех общественных сил, заключающихся в государстве. «Воле монарха установлен жесткий предел общественными отношениями. Воля монарха очень часто наталкивалась на пассивное сопротивление правящих и не правящих слоев страны и не приводила решительно ни к каким результатам». [4, с. 112]. Как видим, автор акцентировал внимание на том, что любой монарх, как и всякая власть в целом, полагается на общественные силы и может быть в затрудненном положении только через их посредство.

Содержательной основой российского публичного интереса, по мысли И.Л. Солоневича, становится на первый взгляд парадоксальное сочетание самодержавия и самоуправления. Иван Лукьянович считал, что они исторически устойчиво поддерживали и взаимодополняли друг друга. Русское самодержавие было направлено русской низовой массой, оно концентрировало в себе политическую организацию и религиозную совесть народа, опираясь на церковь [5, с. 103-112]. Как полагал мыслитель, самоуправление являлось политической организацией народа на его низах, а самодержавие - политической организацией народа в его общности.

И.Л. Солоневич как продолжатель славянофильской традиции в раскрытии государственно-правового аспекта публичного интереса ориентировался на идеалы Московского царства - народной, бессословной, соборной монархии с элементами земского самоуправления. В этой ситуации царь представлял интересы всей нации, а не какой-то отдельной социальной группы. Монарх был наделен необходимой независимостью от дворцовых интриг, поскольку чиновники, находившиеся в промежуточном социальном положении между царем и народом, не имели веской силы, чтобы внести значимое влияние в свою пользу на процесс принятия государственных решений. Исходя из этого, И.Л. Солоневич именовал московскую монархию народной, соборной [6, с. 173-186]. Из этого следует, что народная монархия с местным самоуправлением - идеальное государственное устройство, по мнению И.Л. Солоневича.

Термин «соборная монархия» означает абсолютно реальное историческое явление, прослеженное опытом государственно-правового и социального развития России. Этот термин И.Л. Солоневич предлагает для более четкого понимания политических требований и такой дефиниции, как «конституционная демократическая монархия», которую он перевел на русский язык как «соборная и народная монархия», придавая им национально-самобытное звучание. В своей модели идеального государства Иван Лукьянович уделил внимание и государственному режиму [7, р. 8-9]. Демократическое, многопартийное, народное государство - идеал государственного режима будущей российской монархии. Русская монархия должна опираться не только на юридическую нормативность и экономические основания, но и в первую очередь на моральнонравственные ценности.

Отстаивая монархию, И.Л. Солоневич скептически относился к республиканской фрорме правления, поскольку был убежден, что при такой форме правления, в частности, не может быть решен национальный вопрос, столь актуальный для России. В зависимости от того или иного случая русская монархия воспринимала каждый национальный вопрос. В целях его решения 
мыслитель составил программу из следующих принципов: отклонение от насильственной русифрикации; право каждого гражданина каждой этнической группы говорить, учиться, печатать на любом языке, предпочитаемом этой группой; русский язык, являясь общегосударственным, сохраняется обязательным и непременным для внешней политики, транспорта, армии и почты. В итоге, по мнению И.Л. Солоневича, стойкость всей национальной жизни России основывается на трех элементах: монархии, церкви и народе.

В заключение можно сделать вывод, что И.Л. Солоневич сформулировал оригинальное, основанное на идее «народной монархии» содержательное раскрытие концепта «публичный интерес» применительно к российской политико-правовой и социальной государственности.

\section{Ссылки:}

1. Hornung K. Konservatismus // Handlexikon zur Politikwissenschaft. 1986. No. 237. S. 57-83.

2. Солоневич И.Л. Народная монархия. М., 2003.

3. Иванников И.А. Проблема эволюции формы российского государства в истории русской политико-правовой мысли второй половины XIX - середины XX в. : дис. ... д-ра. юрид. наук. Ростов н/Д., 2000.

4. Солоневич И.Л. Белая империя. М., 1997

5. Солоневич И.Л. Народная монархия. С. 103-112.

6. Там же. С. 173-186.

7. Andreev N. Popular Monarchy as the political ideal by I. Solonevich // Scientific enquiry in the contemporary world: theoretical basics and innovative approach. San Francisco, 2014. P. 6-10.

\section{References:}

Andreev, N 2014, 'Popular Monarchy as the political ideal by I. Solonevich', Scientific enquiry in the contemporary world: theoretical basics and innovative approach, San Francisco, pp. 6-10.

Hornung, K 1986, 'Konservatismus', Handlexikon zur Politikwissenschaft, no. 237. S. 57-83, (in German).

Ivannikov, IA 2000, The problem of the evolution of the form of the Russian state in the history of Russian political and legal thought in the second half of the 19th century and the middle of the 20th century, D.Phil. in Law thesis, Rostov-on-Don, (in Russian).

Solonevich, IL 1997, The white empire, Moscow, (in Russian).

Solonevich, IL 2003, The people's monarchy, Moscow, (in Russian). 